\title{
Aiding the Internet in Central Asia
}

\author{
Eric McGlinchey \\ Assistant Professor \\ Department of Public and International Affairs \\ George Mason University \\ emcglinc@gmu.edu \\ Erica Johnson \\ Ph.D. Candidate \\ Department of Political Science \\ University of Washington \\ ejj3@u.washington.edu
}

\begin{abstract}
This paper asks why Central Asian governments, though equally repressive of their traditional media, pursue diverging policies toward the Internet. Ultimately we find Internet regulatory policy in the Central Asian states varies according to who provides financial capital for ICT. Where international aid organizations and NGOs provide capital and assistance for ICT infrastructure, such as in Kyrgyzstan and, to a lesser extent, in Uzbekistan, the formal regulatory environment is more open, clearly articulated, and permissive of electronic media. In contrast, where domestic actors fund the development of ICT infrastructure, as in Kazakhstan, regulation is vague and government control and interference more extensive.
\end{abstract}

Draft prepared for the Post-Soviet In/Securities Conference at the Mershon Center, Ohio State University, October 6-8, 2005. 


\section{Aiding the Internet in Central Asia ${ }^{1}$}

Central Asian leaders have, with a few notable exceptions, successfully mixed patronage politics and coercion to perpetuate authoritarian control. Domestic reformers along with multilateral and bilateral aid organizations, for their part, have worked to limit patronage and coercion and to move Central Asian governance beyond the inherited pathologies of the Soviet rule. By their own admission, these domestic and international reformers have had limited success. The World Bank, for example, readily acknowledges that Central Asian leaders have appropriated loans to maintain patronage rule. And, at least in the case of Uzbekistan, bilateral military aid granted as part of the US Global War on Terror has, instead, been appropriated for suppressing domestic populations. Thus, for example, the US purchase of night vision goggles, laptops and Russian made jeeps for the Uzbek border control freed resources for the Uzbek president to buy, among other things, the armored Land Rovers which were used in the bloody May 2005 suppression of protestors in Andijan.

Well-intentioned foreign aid, in short, is often captured and redirected by the region's authoritarian governments: military aid to secure borders is used within those borders for repression; economic privatization loans are used to maintain state run factories; and internationally-run poverty alleviation programs free corrupt leaders to continue line the pockets of domestic supporters. Encouragingly, however, not all aid programs are so easily captured and reapplied toward patronage politics. In one sphere in particular - the electronic media and new information communication technologies (ICTs) - international aid does appear to have liberalizing effects. As we demonstrate in this paper, otherwise authoritarian regimes are willing to adopt permissive electronic media regulations in their quest to obtain aid for developing ICT infrastructure. (Note to readers: we continue to investigate the causal link here-we believe ICT is likely perceived as a marker of status/development in the region and, as such, autocratic leaders are willing to make some concessions in order to obtain donor aid.)

\section{One Media, Many Regulatory Regimes}

Authoritarian governments devote considerable resources to controlling the media. Though critical to the smooth functioning of democracies, free information flows can also lead to instability, protest, and even revolution in authoritarian settings. Rustavi2's widely watched television reports of Georgia's November 2003 sham parliamentary elections, for example, emboldened thousands to take to the streets in Georgia's Rose Revolution (Economist 2003). One year later, in Ukraine, journalists from the 1+1 television station declared in an evening broadcast that they would no longer report "distorted information ... under the direction of various political forces," indicating to the hundreds of thousands of protestors in Kiev's Independence Square that President Kuchma's authoritarian powers had crumbled (Strauss 2004). Indeed, 1+1 confirmed

\footnotetext{
${ }^{1}$ Our research is part of an ongoing study of the effects of information technology on society conducted by the Central Asia + Information and Communication Technologies (CAICT) project at the University of Washington in Seattle. The project is supported by the National Science Foundation under Grants No. 0219350 and 0326101 . The opinions, findings, and conclusions or recommendations expressed in this material are those of the authors and do not necessarily reflect the views of the National Science Foundation. For more information about the CAICT project, see http://depts.washington.edu/caict/.
} 
what some Ukrainians had learned the previous night when the sign linguist for the staterun UT1 news signed, "Don't believe this. It's all lies. Yushchenko is our president” (Strauss). And during the March 2005 political upheaval in Kyrgyzstan, the Internet and other media played an instrumental role in the organization of protests that led to the ousting of President Askar Akayev.

As the recent clamp down on media freedoms in Uzbekistan and Kazakhstan demonstrates, the remaining Central Asian presidents well understand the lessons of their fallen authoritarian colleagues_-information outlets must be managed lest small protests expand into country-wide oppositionist mobilization. And, in contrast to their deposed Ukrainian, Georgian, and Kyrgyz counterparts, Central Asia's autocrats have been more successful in controlling their domestic media. All five Central Asian states have consistently ranked among the most oppressive of all media environments in Freedom House's annual Freedom of the Press surveys. Indeed, in recent years Central Asia's presidents have pursued similar strategies in controlling the media, nationalizing printing presses, radio and television broadcast channels, hamstringing the few independent media outlets that do exist with endless court cases, and restricting the information and communication environment.

Oddly, however, Central Asian leaderships have differed in their policies toward what is potentially the most politically destabilizing of all media outlets - the Internet. For example, while it regularly padlocked the offices of independent print newspapers, the Akayev regime in Kyrgyzstan maintained an open regulatory environment for the country's Internet-based media. In neighboring Kazakhstan and Uzbekistan, in contrast, the state closely controls both the traditional and electronic media. Why should these governments, equally repressive of their traditional media, pursue diverging policies toward the Internet? We argue in this paper that Internet regulatory policy in the Central Asian states varies according to who provides the financial capital for new information and communications technology and infrastructure and financing for development of legislative policies. Where international NGOs provide capital and assistance in drafting legislation, such as in Kyrgyzstan and, to a lesser extent, in Uzbekistan, the formal regulatory environment is more open, clearly articulated, and permissive of electronic media. In contrast, where domestic actors fund the development of ICT infrastructure, as in Kazakhstan, regulation is vague and government control and interference more extensive. In short, in contrast to other studies that have found international aid to produce, at best, mixed outcomes in political and economic liberalization (World Bank 2002) our study suggests that, at least with regards to the electronic media, international partnerships in the initial stages of ICT development can lead to islands of openness in otherwise authoritarian states.

Our discussion proceeds in three parts. In section one we review the literature on ICT in developing countries. This literature is comparatively new and, while scholars have studied the links between economics and ICT development, less understood are the political factors that shape ICT development and the potentially regime-destabilizing consequences that emerge as a result of variations in ICT development. In section two, we turn our attention to the political causes behind varying outcomes in Kazakhstan's, Uzbekistan's and Kyrgyzstan's ICT policy. Here we demonstrate how international partnerships in ICT development, in contrast to what is often the case with other forms of international aid, does produce more liberal regulatory regimes. In conclusion, we 
explore the potential consequences of these variations. Ultimately, we find that, although the current influence of Internet media is less than more traditional print, radio, and television outlets, Internet accessibility and usage is rapidly increasing, particularly among younger generations. As a result, seemingly inconsequential policy variations today may have profound effects on authoritarian stability in the near future.

\section{ICT Regulation and Authoritarian Regimes}

Though several studies investigate the diffusion and adoption of Internet capabilities in developing countries, scholars have devoted little attention to the regulatory environment in which these new ICTs function. For example, in contrast to the growing literature which addresses questions of e-readiness and efforts to bridge the international digital divide between developed and developing countries (see, for example, World Internet Report 2004; Harvard Center for International Development, Wallsten 2003), comparatively little analysis has been devoted to the laws and formal and informal incentives regulating new ICTs in developing countries. Some scholars have, helpfully, studied the political effects of new ICTs in transitional settings.

Problematically though, these analyses focus on the successes while ignoring the many failures of ICT introduction. This selection bias has resulted in overly optimistic hypotheses linking new ICTs to authoritarian regime breakdown. ICT introduction analyses, in short, share much in common with earlier modernization theory studies: they assume that the Internet, like modernization, allows increased communication among the political opposition and thus limits an autocratic leader's ability to maintain uncontested rule (Pye 1990; Knei-Paz 1995; Arterton 1987; Kedzie 1997; Lerner 1958; McLean 1989; Pitroda 1993).

Critics of technological determinism note, however, that governments -indeed authoritarian governments - are often the main, if not only, proponents of technological advancement in developing countries (Kalathil and Boas 2003; Kapur 2002; Rodan 1998). These scholars provide a helpful corrective in that they demonstrate that ICT advancement and political liberalization need not proceed simultaneously, that new ICTs, as witnessed in Singapore, China, Cuba and throughout much of the Middle East, may be used to reinforce rather than weaken authoritarian rule (Gary Rodan 1998; Kalathil and Boas 2003). Our study builds on these findings and argues that regulatory regimes, not technology itself, shape the effects new ICTs have on political change.

Curiously, as the Central Asian cases demonstrate, not all authoritarian states adopt restrictive regulatory policies toward new ICTs. Even when traditional mediaprint, television, radio - are heavily censored, new ICTs may operate with few restrictions. Central to this variation, we argue, are economic and human resource capacity. While government elites may identify adoption of ICT as critical to economic growth, not all states have the financial and intellectual capital necessary to develop and use these modern technologies. In several post-Soviet Central Asian successor states, for example, governments have had to turn to outside actors for ICT equipment and knowhow. And, as the Central Asia cases demonstrate, it matters how state leaders engage the international community in their pursuit of ICT technology. Where states purchase ICT hardware outright and thus require little interaction with foreign donors, authoritarian regimes have succeeded in maintaining control over new electronic media. In contrast, 
where governments must rely on foreign aid to purchase new technologies, states have markedly less authority over the use and application of ICTs.

\section{Overview of the Cases}

Kyrgyzstan, Uzbekistan, and Kazakhstan illustrate this causal link between the role of foreign aid and ICT regulatory regimes. With the assistance of foreign donors, Kyrgyzstan drafted liberal policies for Internet use and regulation. Although the existence of formal written laws does not always reflect practice, the Kyrgyz case demonstrates how Internet users and Internet service providers apply formal legislation to defend their newly acquired ICT rights. Likewise, although Uzbekistan is one of the region's more closed regimes and the international community condemns the Karimov regime as an "enemy of the Internet” (Machleder 2002; Reporters sans Frontiers 2004), in 2002, foreign donors induced Uzbekistan to change its rigid control of the ISP market as a condition for the provision of technology and equipment. By contrast, Kazakhstan, which has benefited from direct foreign investment in oil and natural gas, has been able to purchase ICT equipment outright and, as a result, has seen markedly less interference from foreign donors in the formation and implementation of ICT policies. In sum, as the following case studies suggest, states that depend on international NGOs and aid organizations to fund ICTs have more permissive ICT regulatory regimes. In contrast, economically self-sufficient states control the internet much as they do other media. As we note in conclusion, these findings have important implications for the downstream effects of foreign funding and political liberalization in developing countries.

\section{Kyrgyzstan}

Starting in 1993-94, international donor and development organizations made significant contributions to the adoption of ICT in Kyrgyzstan. International organizations supplied the Kyrgyz government with software and extensive computer and network equipment (Nusurov 2002). Moreover, the international community was active not only in the building the ICT infrastructure, but also in the implementation of appropriate legislation (Mikosz 2004).

In 1995 Kyrgyzstan adopted its first national ICT plan. A shortage of funds, however, delayed the ICT development and the plan's implementation (Perraton 2004: 55). Hoping to overcome financial constraints, Kyrgyzstan's leadership turned to the international community for aid in developing the country's ICT infrastructure. USAID, UNDP, and the Soros Foundation responded to Kyrgyzstan's petition, supplying experts and hardware as well as considerable advice on how to draft, design and implement an ICT regulatory regime. By most measures, foreign aid has had a liberalizing effect; in a recent review, the UNDP cited Kyrgyzstan's ICT development and regulation as a "best practice” example for other countries in the developing world (Perraton 2004: 55; Mikosz 2004).

Partially as a result of its comparatively early decision to develop new telecommunication policies, ICT statutes in Kyrgyzstan are more straightforward than in the other Central Asian countries. Three laws - the Law on Communications, the Law on Licensing, and the Law on Informatization-regulate activities of ICT companies. One agency, the Ministry of Transport and Communications, is the state institution responsible for the management and regulation of new ICTs in Kyrgyzstan. Ultimately 
however, it has been the foreign aid community as much domestic laws and supervising agencies that have shaped ICT development in Kyrgyzstan.

As part of the first telecommunication project funded by the World Bank and the EBRD, Kyrgyztelecom, a joint-stock company, received exclusive control of longdistance and international telephone service. Importantly though, within the framework of this same project, the World Bank required the non-participation of Kyrgyztelecom in communication sectors other than telephony (Kyrgyzstan Development Gateway 2001). Thus, Kyrgyztelecom was to provide network infrastructure for private operators and, in turn, inter-operator tariff agreements were to be concluded on a competitive basis, subject to antimonopoly regulation. It should be noted that in 2002 Kyrgyztelecom did receive a nationwide license to offer Internet access. The number of private ISPs, however, continues to grow. Moreover, these private ISPs have begun to challenge Kyrgyztelecom's presence in the market. For example, through the industry group, the Internet Club Public Union, private ISPs have charged that Kyrgyztelecom is violating antimonopoly practices by not charging long distance fees customers using dial-up access (Nusurov 2002; BISNIS 2003a).

Between ten and fifteen ISPs now operate in Kyrgyzstan, the greatest number of ISPs in any Central Asian country. Access to the internet has been further aided by the proliferation of private and non-governmental Internet centers and cafes. Moreover, a NATO funded connectivity project has provided educational institutions, libraries, and hospitals with ICT and satellite equipment so as to provide free Internet access to Kyrgyz citizens throughout the country (Ukrainian Times 2003).

Encouraged by its international donors, the Kyrgyz state has itself assumed a leading role in furthering public access to new ICTs. Internet access, for example, is provided to prisoners in Kyrgyzstan's prisons (BBC Monitoring 2004a). The state, moreover, has opened free Internet centers in rural areas, a critical step in advancing connectivity given that more than half of the Kyrgyz population lives outside major cities. Other indicators of Kyrgyzstan's progressive approach to new ICTs include egovernance projects to further state transparency as well as the decentralization of licensing for Kyrgyz domains. Thus, the private ISP, Asia-Info, registers all "dot-KG" domains in the country (Kyrgyzstan Development Gateway 2001: 26).

This comparatively liberal ICT regulatory framework stands in marked contrast to the Kyrgyz government's policy toward traditional media. As is the case elsewhere in Central Asia, the Kyrgyz print, radio and television media have faced considerable constraints in what they can and cannot report. Until Freedom House opened its own press in 2004, for example, the government controlled the only operating press in the country. Self-censorship, not surprisingly, was common as were sudden "breakdowns" of the government press when opposition papers attempted to print articles critical of the central administration. Revealingly however, whereas the government cancelled newspaper runs and muted criticism on television and radio programs, internet-based media reporting has continued relatively unhampered by state intervention.

\section{Kazakhstan}

In contrast to the Kyrygz government, the Nazarbaev regime in Kazakhstan has maintained strict authority over the Internet. Here, the government's desire for monopoly power is matched by real state capacity to ensure unrivalled control. The Nazarbaev 
government, awash in oil money, is the richest in Central Asia. During its first decade of post-Soviet independence, Kazakhstan received as much foreign direct investment as did Russia, a country with a population ten times the size (World Bank WDI). And unlike his Kyrgyz counterpart's dependence on international aid and grants, President Nazarbaev effectively applies oil revenues to dictate the course of ICT development in Kazakhstan.

Whereas Kyrgyzstan's international dependence constrained the central government, Kazakhstan's oil wealth affords the Nazarbaev government influence over both the principals and the policies of ICT infrastructure. Two government-owned telecommunication companies, Kazakhtelecom and Nursat, control the Internet market in Kazakhstan. Throughout the 1990s, these government monopolies were sufficient to ensure new ICT media did not threaten Kazakhstan's authoritarian government. Kazakhtelecom, for example, controls about 70 percent of the internet access market (Johnson 2003). Although the Kazakhtelecom and Nursat monopolies persist today, the Nazarbaev government has begun to develop new, regulatory strategies of control. Kazakhstan, like many post-Soviet states, covets membership in international organizations such as the WTO. And should Nazarbaev discover WTO membership is conditional on breaking the Kazakhtelecom and Nursat monopolies, the state's new ICT regulations will ensure that Kazakh government maintains control over electronic communications.

That the Kazakh government maintains monopoly control over Internet service providers does not mean that it has entirely eschewed foreign ICT investment. As in other Central Asian states, Kazakhstan's ICT industry is in its infancy and, as a result, Kazakhtelecom and Nursat have had to contract with outside companies such as Seimens, WorldCom, Nortel, Cisco, and Lucent Technologies to provide fiber optics and digital switching equipment. Most international companies have been content simply to provide hardware and leave Internet and telecommunications provision to the Kazakh monopolies. A few, however, have attempted to enter Kazakhstan's ICT provider market. The ease with which the Nazarbaev government has thus far dismissed these attempts demonstrates the advantages oil wealth conveys to authoritarian governments confronted with potentially destabilizing new technologies.

The Nazarbaev regime has employed multiple strategies to limit foreign acquisitions of and influence over the Kazakh ICT market. One effective policy has been to stall negotiations and to refuse contract guarantees to foreign investors. In 1996, for example, Deutsche Telekom sought to acquire a 49\% stake in Kazakhtelecom. In return for capital investment, the German company would gain control of the Kazakh monopoly for six years. Deutsche Telekom was ultimately scared away, however, when the Nazarbaev government refused to commit to new tariff hikes and to a clearly defined foreign operator license (Williamson 1998).

Another strategy has been simply to deny foreign companies the chance to acquire shares in the Kazakh ICT majors. In September 2000, for example, the Kazakh government denied Moscow-based Golden Telecom's attempt to buy a $10 \%$ stake in Nursat. The Kazakh Transport and Communications Minister, Karim Masimov, justified his government's rejection of the Russian company's bid by appealing to national defense: "I think it would be wrong if a company which provides the government with 
communications was controlled by a private company.... We are talking about national security” (Interfax-Kazakhstan 2000).

Security indeed is an overriding concern of the Kazakh political elite. It is likely their own security, however, more than that of the nation, about which they are most worried. The Kazakh opposition has attempted and occasionally succeeded in using the internet as a tool to mobilize opposition against the Nazarbaev regime. Thus, through websites such as Eurasia.org.ru and the online newspapers, Navigator and Assandi-Times, the Kazakh opposition has repeatedly exposed corruption and graft in the presidential administration. Such exposés have unnerved the governing elite. Information, Culture and Public Consent Minister Altynbek Sarsenbayev, for example, fretted that some of these new websites have a readership that "outstripped Kazakh media in terms of the daily readers” (Agence France Presse 2001).

Monopoly control, importantly, allows the Nazarbaev government to block Kazakh citizens' access to what is deemed offensive online papers. Initially, Kazakhtelecom and Nursat officials denied that the government had instructed them to block oppositionist websites, claiming instead that access problems were due to "technical" problems with the sites themselves (IPR 2000). More recently, however, the Kazakh government has hobbled opposition websites by subjecting them to the same draconian media laws it had long been applying to newspapers and broadcast journalism. ${ }^{2}$ The popular internet paper, Navigator, to take one prominent example, was fined \$32,000 in January 2003 for allegedly libeling President Nazarbaev's son-in-law in 2003 (IPR 2003). And, further tightening the screws on the electronic media, in July 2003 the Nazarbaev government created a new policing body, the Kazakh Agency for Information Technology and Communications, "to implement state policy on information technology and communications” (Interfax-Kazakhstan 2003). Throughout spring and summer 2005, Nazarbayev reportedly barred coverage of the upheaval in Kyrgyzstsan and Uzbekistan from Internet, television, and radio coverage and the government has drafted a new law that introduced greater restrictions on Internet uses (Schwartz 2005; Navi 2005). Thus, on the threshold of the December presidential elections, the Kazakh government has built a regulatory regime that effectively stifles free press in the electronic media-a regime that will persist even if WTO accession does force the end of the Kazakhtelecom and Nursat ISP monopolies.

Nursultan Nazarbaev is likely the envy of Central Asia's other authoritarian leaders. He enjoys the best of both worlds - in the space of fifteen years, he has built a modern ICT infrastructure while, at the same time, through his regime's monopoly control over ISP providers, he has limited the regime-destabilizing effects that often accompany ICT modernization. Whereas the Kyrgyz government was forced to concede a significant degree of control over electronic media in return for international aid in developing the ICT sector, the Kazakh state was able to apply its oil wealth to buy a modern telecommunications infrastructure outright, no strings attached. Paradoxically, at least in the Central Asia cases, it is poverty rather than wealth that leads to a more competitive, vibrant, and free telecommunications and electronic media environment.

\footnotetext{
${ }^{2}$ In April 2001, the Kazakh parliament passed a new media law making websites subject to the same libel laws as are print and broadcast media. See, for example, "Parliament Passes Strict Media Law," IPR Strategic Business Information Database, April 22, 2001.
} 


\section{Uzbekistan}

Well known for oppression of opposition groups, Islam Karimov's authoritarian regime exercises tight control over the flow of both traditional and new ICT media in Uzbekistan. To a limited degree, the international community has influenced Uzbekistan's ICT policies through the conditional provision of equipment. Nevertheless, ICT regulation remains vague. Instead of a coherent ICT regulatory regime, the restrictive laws which control the traditional media are applied to the Internet. The Uzbek state's control, importantly though, is not complete. Freedom House has found, for example, that the Uzbek government's restrictions on Internet content are less severe than those used to control traditional print and broadcast media (Sussman 2001).

Likely in part responsible for this rare opening in the electronic media is the complex and confused network of regulatory bodies which are tasked with governing ICT in Uzbekistan. More than fifteen laws, including Uzbekistan's Constitution, muddled Civil and the Taxation Codes, and the state's Administrative Liability Code regulate the ICT sector (UNDP 2003). Tasked with enforcing these codes is an equally complex array of regulatory bodies - the National Security Service, the Ministry of Defence, the Uzbek Agency of Communications and Informatization, and the Cabinet of Ministers.

Despite this confused delineation of regulatory responsibility, the Uzbek government has periodically attempted to exert influence over the Internet despite the protests of international aid organizations. In 1996 a concert of aid organizations including UNDP, USAID, and the Open Society Institute began providing Uzbekistan with ICT equipment and technical support. Less sanguine about Uzbekistan's autocratic Karimov government, however, donors extended considerably less ICT than they did to Kyrgyzstan. (Note: We're working on concrete measures to demonstrate this - the variation in aid is substantial but we are struggling with the $\$$ \$ numbers and how best to demonstrate this variation). As a result, the Karimov leadership has been less beholden to foreign donors and better able to shape the Uzbek internet to serve state ends than has the Kyrgyz government. Until recently, for example, the state-controlled UzPak group maintained exclusive monopoly rights as Uzbekistan's sole ISP. As a result, the Uzbek government could easily restrict access to external information channels. ${ }^{3}$ Other companies had been able to lease bandwith from UzPak. Though nominally independent, these private ISPs nevertheless remained prisoner to the UzPak filter, which, according to official rhetoric, the state maintained so as to combat terrorism.

USAID and the Open Society Institute were not convinced by the state's terrorism explanation and, in the late 1990s, these aid organizations withdrew their ICT support to the Uzbek government. The withdrawal of aid at first appeared to have little effect on the Karimov leadership. In 2001, however, the UNDP conducted an e-readiness assessment of Uzbekistan which demonstrated that the country had quickly fallen behind countries with which it had once maintained ICT parity (UNDP 2003: 1). Shortly after these findings became public a chagrined Uzbek state liberalized its ICT regulatory regime in the hopes of securing foreign aid. To a limited degree the Uzbek state's new ICT policies have yielded results; in addition to its modest liberalization, ICT development in Uzbekistan is now proceeding with bilateral support from Great Britain, Germany, the

\footnotetext{
${ }^{3}$ This model has also been used by Singapore and China (among others) as a way to maintain state control of what some have deemed a medium that defies regulation (Kalathil and Boas 2003; Rodan 1998).
} 
United States, Switzerland, Japan, and Spain and multilateral aid from the UNDP, World Bank, EBRD, ADB, the European Union, and USAID.

Despite limited reform, though, the development of the ICT sector in Uzbekistan is nevertheless a mixed story. Observers suggest that Uzbekistan now has as many as 263 registered ISPs. Only 35-40 of these ISPs, however, likely are actually operating. Moreover, the majority of Uzbekistan's ISPs are in the capital city Tashkent and only a handful of these providers have connections to international channels independent of the UzPAK network (Gidaspov 2001; U.S. Embassy Tashkent 2001). In reality, Uzbekistan's ISP market is divided between UzPAK and the private company Naitov, which together control approximately 80-85 percent of the market (Avdeeva and Jalilov 2002). In short, although the international community's provision of ICT equipment has created some openings for Uzbek Internet users, foreign donors' comparatively constrained role has not encouraged the extent of liberalization seen in the Kyrgyz case.

\section{Conclusion}

Our research demonstrates that the relationship between new ICTs and politics need not be a liberalizing one. President Reagan's prediction, alas, has not proven true; "the Goliath of totalitarianism" has not succumbed so easily to "the David of the microchip" (Kalathil and Boas 2003). Indeed, the spread of new information and communications technology, rather than encouraging democratization, can have decidedly illiberal effects on governance. When authoritarian governments have the economic wherewithal to purchase ICT hardware, as the oil rich Kazakh government does, new technologies further autocratic control. Importantly though, where governments are forced to turn to international donors and businesses to fund ICT acquisition, as has been the case in Kyrgyzstan and, to a lesser degree, in Uzbekistan, authoritarian control is less assured and electronic media can have dramatic political effects. Tajikistan is, by contrast, an intermediary case, where foreign aid has not yet filled in for insufficient domestic resources and government control of ICTs prevails. In short, foreign aid and conditionality, while it often fails to promote reform in other spheres of governance (Knack 2004; Remmer 2004; McGlinchey 2003), can lead to more open ICT environments.

Critically, while the liberalizing effect of these more open ICT environments is by no means certain, recent uprisings in Central Asia do offer insights into what, in conclusion, we suggest may be the changing nature of social mobilization, protest, and revolution. Social science scholars instruct that mass uprisings are rare events, so rare that scholars have all but conceded a theory of revolution is unlikely. Indeed, rather than delineating those conditions which lead to social upheaval, scholars have instead concentrated attention on why societies are so seemingly willing to tolerate repressive rule (Skocpol 1979, Olson 2000).

While we do not offer a new theory of revolution, we do believe, that recent uprisings in authoritarian Uzbekistan and Kyrgyzstan, as well as mass protest movements elsewhere in the authoritarian world, demand a rethinking of long standing assumptions in the social mobilization literature. Most scholars of protest and opposition employ a mixture of structural and rational choice logics in their explanations of why societies more often than not are docile in the face of authoritarian rule. From the structural side, revolutions are thought to occur only in those rare occasions when state institutions prove 
insufficient to contain or repress societal demands (Huntington 1968, Skocpol 1979). Similarly, from the rational choice end, mass uprisings materialize during rare periods when individuals perceive that protest will produce policy or regime change, rather than leading to personal harm, (Kuran 1991). Though structural explanations begin with the state whereas rational choice narratives emphasize the individual, the causal mechanism is the same-repressive state capacity ensures individuals rarely surmount the collective action challenges necessary for mass uprising or revolution.

Jail, torture, and death indeed have proven to be strong disincentives to protest. Yet, in other contexts, people are willing to accept terrible risks in the pursuit of strongly held beliefs - soldiers enter battles knowing the chance for injury or death is high. Similarly, health and aid workers volunteer in war zones, well knowing that personal safety and financial remuneration may be far greater at home. Why should risk calculations differ in these examples than in the cases of popular protest?

The explanation lies in the value of socially constructed meaning. In order to perceive the efficacy of individual action, indeed for there to be efficacy in individual actionpeople must believe their behavior will affect others. The soldier goes to battle because she sees the value in her contribution to the battalion and the greater war effort. Likewise, the health worker enters war zones because he can see the improvement in the welfare of his patients. Until now, however, the oppositionist and would be revolutionary in the vast majority of cases could see protest leading only to anonymous suffering at the hands of an authoritarian state. What use is protest if state control is such that opposition goes unnoticed by one's neighbors?

In the past, repressive regimes could disappear activists, regimes could deprive protest of social content by rigidly controlling information networks. Today, however, even the Uzbek regime—among the world's most authoritarian—cannot hide its repression.

Whereas in the past fears of unrecognized — and thus, meaningless—repression acted as a check on political opposition, the rise of new and difficult to control ICTs encourages protest even in states where all other forms of repressive capacity remains strong.

In short, while we cannot pinpoint when and in which authoritarian states uprisings will occur, we can predict that, given the nature of new ICTs, the incidence of uprisings and, as a result, political instability will be greater than it has ever been in the past. As such, understanding what causes variations in ICT regulatory regimes in otherwise similarly authoritarian states is ever more critical to theorizing about the (in)stability of non-democratic states. Of course, this would not be the first time innovations in technology forced social scientists to adjust theories of political change. Print capitalism gave rise to standardized language and, in turn, the imagined identity of the nation (Anderson 1991). Similarly, new ICTS — cell phones and the internet in particular—give immediate meaning to what, in the past, would have been unrecognized acts of individual opposition. In the process, today's innovative ICTs have enabled a new language of popular protest. Encouragingly, in some cases instability and protest may lead to revolutionary political reform. Here, the role of foreign aid and its liberalizing effects on ICT regulation is undeniably positive. The past fifteen years of post-Soviet Central Asian instability and uprising, though, serve as a sober reminder that political instability and the overthrow of one authoritarian regime does not preclude the rise of new forms of illiberal rule. New communication technology aids proponents of political reform; however ICT alone cannot guarantee future democratization. 


\section{References}

Agence France Presse, 2005, "Independent weekly newspaper in Tajikistan seized by authorities,” January 28, in LexisNexis

Agence France Presse, "Kazakhstan Seeking to Control What Citizens See on the Internet,”January 25, 2001. Available on line, Lexis-Nexis.

Anderson, Benedict, 1991, Imagined Communities: Reflections on the Origin and Spread of Nationalism, New York: Verso.

Anderson, B., and K. Tracey, 2001, "Digital living: The impact (or otherwise) of the Internet on everyday life,” American Behavioral Scientist, 45 (3), 456-75.

Arterton, Christopher F., 1987, Teledemocracy: Can Technology Protect Democracy? Newbury Park, CA: Sage Publications.

Asia-Plus, 2005, "Situation with Tajik Media Deteriorating - Journalist,” February 3, BBC Monitoring/BBC Monitoring International Reports, February 14, 2005, in LexisNexis.

Asia-Plus, 2004a, “OSCE to Open Centre for Tajik Journalists with Free Internet," October 1, 2004, BBC Monitoring/BBC Monitoring International Reports, in LexisNexis.

Asia-Plus, 2004b, “Tajikistan: Journalists 'Systematically' Threatened for Critical Articles,” Aug 11, BBC Monitoring/BBC Monitoring International Reports, in LexisNexis.

Asia-Plus, 2004c, "Central Asian Media Watchdogs Unite to Defend Journalists' Rights Tajik Agency,” February 25, BBC Monitoring International Reports, in LexisNexis.

Asia-Plus, 2003a, “New Internet Provider Starts Operation in Northern Tajikistan,” July 24, Monitoring/BBC Monitoring International Reports, LexisNexis.

Asia-Plus, 2003b, “Iran, China Help Tajikistan Modernize Telephone System,” July 15, BBC Monitoring/BBC Monitoring International Reports, in LexisNexis.

Asia Pulse, 2005, “The Internet Makes Slow Progress in Tajikistan,” May 6, 2005.

Associated Press, 2004, “U.S. Embassy expresses concern over media freedom in Tajikistan,”August 25, in LexisNexis.

Associated Press, 2003, “Independent newspaper out of print in Tajikistan,”December 3, in LexisNexis

Associated Press Worldstream, 2003, “Tajik political parties protest suspension of independent newspaper,” December 12, 2003, in LexisNexis).

Avdeeva, Yulia and Shakhruh-Mirzo Jalilov, “Oputanannye set'yu...Interneta (Obzor rynka internet-uslug),” Ekonomicheskoe obozrenie (Internet version), 2002, no. 1, http://www.review.uz/archive/article.asp?y=2002\&m=34\&id=25.

Avesta, 2005a, "Eurasia Foundation to Help Develop Broadcast Media in Tajik Regions,” Text of report by Tajik web site on March 12, 2005, BBC Monitoring/BBC Monitoring International Reports, March 13, 2005, in LexisNexis.

Avesta, 2005b, "What does the Social Democratic Party of Tajikistan want: revolution or lawfulness?" March 14, BBC Worldwide Monitoring, in LexisNexis.

Avesta 2005c, “Tajik broadcast media heads rap new draft licensing rule,” April 8, BBC Worldwide Monitoring, in LexisNexis.

Avesta, 2004, “Media Watchdog Boss Says Journalists 'Afraid of Telling the Truth,'” BBC Monitoring/BBC Monitoring International Reports, in NexisLexis.

BBC, “BBC Country Profile for Kyrgyzstan,” January 7, 2004, in LexisNexis. 
BBC Monitoring, 2005, "Uzbek secret services said using dissidents' emails to send abuse,” January 11, in LexisNexis.

BBC Monitoring, 2004a, "Female Convicts in Kyrgyz Prison to Surf Internet, August 19, 2004, in LexisNexis.

BBC Monitoring, 2004b, "Overview of the Media in Tajikistan - Updated 17 April 2004,” BBC Monitoring/ BBC Monitoring International Reports, April 17, in LexisNexus.

BBC Monitoring, 2003a, “Kyrgyz Internet Clubs Say State Agency Restricting Access to Internet,” December 5, in LexisNexis.

BBC Monitoring, 2003b, "Uzbek Internet Providers Accused of Censoring Antigovernment Web Sites,” November 18, in LexisNexis.

BBC Monitoring, 2003c, "Few Media Outlets Operating Stably in Kyrgyzstan, Agency Says," September 17, in LexisNexis.

Beeman, William O., 2004, “On the 'New Silk Road' - On balance, life is better in Tajikistan,” The Providence Journal (Rhode Island), August 10.

BISNIS, 2003a, “Kyrgyz Republic: Commercial and Economic News,” December, http://www.bisnis.doc.gov/bisnis/bisdoc/0312KG_Comm_News_Update.htm.

BISNIS, 2003b, "Kyrgyz Republic: List of Telecom Companies, ISPs, and Cellular Service Providers,” July, http://www.bisnis.doc.gov/bisnis/bisdoc/0308telekg.htm.

Borisov, Akbar, 2004, “Tajikistan touches base with the outside world in Internet boom,” Agence France Presse, July 17.

Center of Economic Research (Tsenter Economichkikh Issledovaniyi), “Informatsionnye tekhnologii na sluzhbe razvitiya,” Ekonomicheskoe obozrenie (Internet version), 2002, no. 6, http://www.review.uz/archive/article.asp?y=2002\&m=47\&id=78.

Collier, Paul, and David Dollar. 1999. Aid Allocation and Poverty Reduction. Working Paper of the World Bank:1-33.

Dunning, Thad, 2004, "Conditioning the Effects of Aid: Cold War Politics, Donor Credibility, and Democracy in Africa. International Organization 58 (2): 409-423.

The Economist, “A Moment of Truth,” (November 27, 2003).

e-Living: Life in a Digital Europe, 2002, Retrieved February 7, 2005, from http://www.eurescom.de/e-living/.

Financial Times, 2003, “Tajik, Afghan Communications Ministers Discuss Cooperation,” BBC Monitoring/International Reports, June 20, in LexisNexis.

Gidaspov, Andrey, 2001, “Internet Security,” Industry Canada, March 19, http://strategis.ic.gc.ca/epic/internet/inimr-ri.nsf/en/gr-776210e.html.

Goldsmith, Arthur, 2001, "Foreign Aid and Statehood in Africa,” International Organization, 55:1.

Great Game Travel Company Web Site, 2003, “Travel Tajikistan,” Accessed July 25, 2005, http://www.traveltajikistan.com/practicalities/internet.html\#internet_access_provider s.

Herbison Consulting, 2004, “Tajikistan Internet Access Providers List,” http://herbison.com/iap_meta_list/iap_meta_list_tj.html).

Huntington, Samuel, 1968, Political Order in Changing Societies, New Haven: Yale University Press. 
Interfax-Kazakhstan News Agency, "US Bid for Stake in Telecom Firm Turned Down," September 29, 2000. Available on line, Lexis-Nexis.

Interfax-Kazakhstan News Agency, "Kazakh Government Lays Out Tasks of New

Telecom Agency,” July 29, 2003. Available on line, Lexis-Nexis.

Interview with Shaukat Valitov in RFE-RL Newsline, October 19, 2003.

IPR Strategic Business Information Database, "Access to Eurasia Website is Blocked Again,” October 30, 2000. Available on line, Lexis-Nexis.

IPR Strategic Business Information Database , "Internet Paper Under Threat of Closure,” January 19, 2003. Available on line, Lexis-Nexis.

IREX, Media Sustainability Index 2004: The Development of a Sustainable Media in Europe and Eurasia, Washington, DC: International Research and Exchanges Board and United States Agency for Information and Development, 2004, http://www.irex.org/msi/.

ITAR-TASS, 2005, "Energy, Communications Priority in Cooperation with Kyrgyzstan Tajik Leader,” May 18, BBC Monitoring/BBC Monitoring International Reports, in LexisNexis.

ITAR-TASS, 2004a, “Tajik Media Moving Towards Press Freedom - Experts,” ITARTASS news agency, May 3, 2004, BBC Monitoring/BBC Monitoring International Reports, in LexisNexis.

ITAR-TASS, 2004b, "US Business Information Service Opens Site in Tajikistan," February 24, BBC Monitoring/BBC Monitoring International Reports in LexisNexis.

Johnson, Eric, 2003, “The Internet in Central Asia," presentation to Media Challenges in Central Asia, RFE-RL Conference, Prague, April 4-5, 2003, http://www.regionalanalysis.org/specialreports/specialreports/en/2003/04/john_speec h.asp.

Kalathil, Shanthi and Taylor C. Boas, 2003, Open Networks, Closed Regimes: The Impact of the Internet on Authoritarian Rule, Washington, DC: Carnegie Endowment for International Peace.

Kapur, Sandeep, 2002, “Developing Countries and the New Economy.” WIDER Discussion Paper.

Kedzie, Christopher R., 1997, Communication and Democracy: Coincident Revolutions and the Emergent Dictator's Dilemma, Santa Monica, CA: RAND.

Khadivi, Roshan, 2002, “GIPI Tajikistan Helps Keep Internet Affordable,” Internews Tajikistan, May 13, http://www.internews.org/news/2002/20020513_tj/20020513_tj.htm.

Kimmage, Daniel, 2005a, “Uzbek Cell Phone Sector Attracts Investments,” RFE/RL NEWSLINE Vol. 9, No. 121, Part I, June 27.

Kimmage, Daniel, 2005b, “British Development Aid to Uzbekistan Draws Fire,” RFE/RL NEWSLINE Vol. 9, No. 122, Part I, June 28

Knack, Stephen. 2004. Does Foreign Aid Promote Democracy? International Studies Quarterly 48 (1):251-66.

Knei-Paz, Baruch, 1995, "Was George Orwell Wrong? Technology and the Prospects for Democracy," Dissent, 42 (Spring): 267.

Khovar, 2005, “Tajik media freedom situation not good - forum,” May 4, 2005, BBC Monitoring Central Asia Unit, in LexisNexis. 
Kuran, Timur, 1991, "Now Out of Never: The Element of Surprise in the East European Revolution of 1989,” World Politics Vol. 44, no. 1.

Kyrgyzstan Development Gateway, 2001, “Kyrgyzstan E-Readiness Assessment Report,” http://eng.gateway.kg/era_policy.

Lerner, Daniel, 1958, The Passing of Traditional Society: Modernizing the Middle East. Glencoe IL: The Free Press.

Mavlany, Jakhongir, “Telecommunications Sector in Uzbekistan,” Business Information Service for the Newly Independent States (BISNIS) Industry Sector Analysis Report, May 2003, http://www.bisnis.doc.gov/bisnis/bisdoc/030620UZ_Telecom.htm.

McLean, Iain, 1989, Democracy and New Technology, Oxford, UK: Polity.

Machleder, Josh, 2002, "Struggle over Internet Access Developing in Uzbekistan," Eurasia Insight, March 12, http://www.eurasianet.org/departments/rights/articles/eav031202.shtml.

Markova, Mariana, 2004, "Barriers for Information Technology Adoption in Post-Soviet Central Asia,” in Fay Sudweeks and Charles Ess, eds., Proceedings of the Fourth International Conference on Cultural Attitudes Toward Technology and Communication (CATaC), Karlstad, Sweden, July 27-July 1, 2004.

Mikosz, David, 2004, "UNDP as a Catalyst for Change in Kyrgyzstan," How to Build Open Information Societies: A Collection of Best Practices and Know-How, Bratislava: United Nations Development Program, 2004.

Navi, 2005, "Dikaya i nelepaya situatsiya voznikla v kazakhstanskoi zone Interneta," NaviGator-II (web newspaper), http://www.navi.kz/articles/9050.

Nusurov, Erkin, "Kyrgyz Republic: Overview of the Information Technologies Sector," January 2002, Business Information Service for the Newly Independent States (BISNIS) Report, http://www.bisnis.doc.gov/bisnis/isa/020225IT-kg.htm.

OSCE Representative on Freedom of the Media, The Media Situation in Kazakhstan, Kyrgyzstan, Tajikistan, Turkmenistan, and Uzbekistan: Five Country Reports, Vienna: Office of the Representative on Freedom of the Media, 2002, http://foi.missouri.edu/internationalfoi/rep_media_ca_en.pdf.

Olson, Mancur, 200, Power and Prosperity: Outgrowing Communist and Capitalist Dictatorships, New York: Basic Books.

OpenNet Initiative, 2005, “Special Coverage: Information War Intensifies as Unrest in Kyrgyzstan Continues-Motives Remain Unclear as Disruptions Increase, March 5.

Perraton, Hilary, 2004, “Central Asia: Kazakhstan, Kyrgyzstan, Tajikistan, Turkmenistan, and Uzbekistan; ICT Use in Education,” in Meta-survey on effective use of ICT, UNESCO, http://www.unescobkk.org/fileadmin/user_upload/ict/Metasurvey/centralasia.pdf.

Pitroda, Satyan (Sam), 1993, “Development, Democracy, and the Village Telephone,” Harvard Business Review, Nov/Dec.

Project POINT Summary. (n.d.). University of California at Irvine, Center for Research on Information Technology and Organizations (CRITO). Retrieved February 9, 2005, from http://www.crito.uci.edu/point2.asp.

Pye, Lucian W., 1990, "Political Science and the Crisis of Authoritarianism,” American Political Science Review, 84: 9 (March). 
RIA OREANDA, 2005, "First in CIS Third Generation Network of Cellular

Communication of UMTS Standard to BE Launched in Tajikistan,” Economic News, June 24.

Remmer, Karen L. 2004. "Does Foreign Aid Promote the Expansion of Government," American Journal of Political Science 48 (1): 77-92.

Reporters Sans Frontieres, 2005, "Tajikistan: Media Harassment Increases in the Run-Up to Elections," Press Release, BBC Monitoring International Reports, February 4, in LexisNexis.

Reporters Sans Frontiers, “Uzbekistan,” 2004 Annual Report, http://www.rsf.org/article.php3?id_article=9968.

Rodan, Gary, 1998, “The Internet and Political Control in Singapore,” Political Science Quarterly, vol. 113, no 1.

Rotar, Igor, 2003, "Uzbekistan: New controls on access to religious websites," F18News, June 19, 2003, www.forum18.org/Archiev.php?article_id=86.

Sadowsky, George, 2002, "Changing Internet Policy: Experience from 17 Countries," presentation for Global Internet Policy Initiative, www.internetpolicy.net.

Schwartz, Stephen, 2005, "The Kyrgyz Take Their Stan; A democratic revolution in Central Asia?” The Weekly Standard, April 11.

Skocpol, Theda, 1979, States and Social Revolutions: A Comparative Analysis of France, Russia, and China, New York: Cambridge University Press,

Stanford University Quantitative Study of Society, 2001, Internet and Society Study, retrieved February 9, 2005, from http://www.stanford.edu/group/siqss/Press_Release/internetStudy.html.

Strauss, Jilius, 2004, "TV Journalists Remove Their State-Imposed Gag to Report Both Sides,” The Daily Telegraph, November 27, p. 17.

Sussman, Leonard R., 2001, The Internet in Flux: Press Freedom Survey 2001, http://www.freedomhouse.org/pfs2001/pfs2001.pdf.

Tajikistan Development Gateway, 2005, “Telecommunications,” http://www.tajikgateway.org/index.phtml?lang=en\&id=920, Accessed August 3, 2005.

UNDP and Communication and Information Agency of Uzbekistan, ICT Development Monitoring in Uzbekistan, Tashkent: UNDP, June 2003, http://www.ddi.uz/page.php?pageid=42\&language=eng.

Ukrainian Times, “In Kyrgyzstan, Some Institutions Get Free Access to Internet,” April 27, 2003, in LexisNexis.

U.S. Embassy Tashkent, 2001, "Uzbekistan’s Hardware and Software Markets Overview,” BISNIS, www.bisnis.doc.gov/bisnis/isa/011114comps.htm.

US Fed News, 2005, “Gift of Books, Connectivity to Vakhsh School,” April 1, in LexisNexis.

Wallsten, Scott, 2003, "Regulation and Internet Use in Developing Countries,” AEIBrookings Joint Center Working Paper, January, http://www.aeibrookings.org/admin/authorpdfs/page.php?id=262.

Williamson, John "Eastern Europe: \$120bn of Investments Needed," Financial Times, June 10, 1998, p. 8.

World Bank, Operations Evaluation Department, "Kyrgyz Republic Country Assistance Evaluation,” (Washington, D.C., 12 November 2002). World Development Indicators. 
World Internet Report, 2004, University of Southern California, Center for the Digital Future, http://www.digitalcenter.org/pages/current_report.asp?intGlobalId=19.

Yakovleva, Tatiana, 2002, "Eastlink—Easy to Pronounce Name and Heavy Fate," Internews Uzbekistan, 99 (August), http://www.internews.uz/bulletin/99August2002.html. 